\title{
Vetores virais para uso em terapia gênica
}

\section{Viral vectors for gene therapy}

Bárbara de Alencar Oliveira', Eliane dos Santos França', Viviane Guimarães Souza', Antonio Carlos Rosário Vallinoto², Andréa Nazaré Monteiro Rangel da Silva²

' Universidade Federal do Pará, Instituto de Ciências Biológicas, Belém, Pará, Brasil

2 Universidade Federal do Pará, Instituto de Ciências Biológicas, Laboratório de Virologia, Belém, Pará, Brasil

\section{RESUMO}

A terapia gênica tem como princípio a transferência de material genético para dentro das células de um indivíduo, com o intuito de corrigir genes responsáveis por características patológicas e, assim, tratar doenças. Desse modo, a entrega eficiente e a expressão apropriada dos genes terapêuticos são requisitos fundamentais para a eficiência da terapia gênica. Diante disso, os vírus se apresentam como importantes sistemas para a transferência de genes, sendo utilizados como uma excelente estratégia para o tratamento de doenças monogênicas e não monogênicas. Os vetores virais baseados em retrovírus, adenovírus, vírus adenoassociados, herpesvírus e poxvírus têm sido estudados para o tratamento de doenças monogênicas, incluindo a doença granulomatosa crônica, a imunodeficiência combinada grave ligada ao X e a deficiência da enzima adenosina desaminase, assim como para as doenças não monogênicas como o câncer. A presente revisão objetiva explorar os aspectos mais relevantes do uso de vetores virais na terapia gênica. Embora sejam eficientes na entrega do material genético, os vetores virais apresentam risco de infecção, ativam a resposta imune do hospedeiro e podem apresentar um potencial oncogênico. Assim, para que a terapia gênica possa ser aplicada na rotina clínica, muitas pesquisas ainda são necessárias para o refinamento e aperfeiçoamento da técnica, incluindo o desenvolvimento dos vetores virais.

Palavras-chave: Vetores Genéticos; Terapia Genética; Doenças Genéticas Inatas; Câncer.

\begin{abstract}
The gene therapy is designed to introduce genetic material into an individual's cells in order to correct genes responsible for pathological features and thus to treat diseases. Thereby, the efficient delivery and the appropriate expression of therapeutic genes are fundamental requirements for the gene therapy efficiency. Accordingly, the viruses are important systems for genes transference and have been used as an excellent strategy in the treatment of monogenic and non-monogenic diseases. The viral vectors based on retroviruses, adenoviruses, adeno-associated viruses, herpesviruses and poxviruses have been studied for the treatment of monogenic diseases, including chronic granulomatous disease, $X$-linked severe combined immunodeficiency and adenosine deaminase deficiency, as well as non-monogenic diseases such as cancer. This study aims to explore the most relevant aspects of the use of viral vectors in gene therapy. Although they are effective in delivering genetic material, the viral vectors present risk of infection, activate host immune responses and may present oncogenic potential. Thus, for the gene therapy to be applied in the clinical routine, more studies are necessary to improve the technique, including the development of viral vectors.
\end{abstract}

Keywords: Genetic Vectors; Gene Therapy; Genetic Diseases, Inborn; Cancer.

\author{
Correspondência / Correspondence: \\ Andréa Nazaré Monteiro Rangel da Silva \\ Universidade Federal do Pará, Instituto de Ciências Biológicas, Laboratório de Virologia \\ Rua Augusto Corrêa, 01. Bairro: Guamá. CEP: 66075-1 10 - Belém, Pará, Brasil - Tel.: +55 (91) 3201 -8410 \\ E-mail: andrearangel@ufpa.br
}




\section{INTRODUÇÃO}

No século XX, ocorreram muitos avanços no campo da biologia molecular, por meio de técnicas que possibilitaram o mapeamento do genoma humano e de doenças monogênicas, as quais serviram de base para o desenvolvimento da terapia gênica'. No final da década de 1970 e começo dos anos 1980, iniciaram-se pesquisas com subclonagem de genes de mamíferos em plasmídeos e bacteriófagos ${ }^{2}$. Nesse mesmo período, foram desenvolvidas técnicas de transferências de genes para células de mamíferos utilizando retrovírus como vetores virais. Essas pesquisas e estudos clínicos foram os precursores da terapia gênica em humanos ${ }^{2}$.

Com o conhecimento de que muitas doenças provinham de alterações genéticas e com o advento da tecnologia do DNA recombinante, surgiu a ideia de tratar as doenças manipulando e alterando a sequência do ácido nucleico das células doentes. Em 1978, David Baltimore, um microbiologista americano, afirmou que seria "o triunfo da medicina se os genes defeituosos pudessem ser silenciados" ${ }^{13}$.

A terapia gênica foi considerada uma alternativa para tratar doenças, cujos procedimentos clínicos já adotados não estavam se mostrando eficazes ou eram inexistentes ${ }^{4}$. Enquanto a terapia convencional procurava aliviar os sintomas de forma transitória, a terapia gênica apresentava como proposta tratar a base genética das doenças ${ }^{5}$.

A princípio, a terapia gênica tinha como objetivo tratar doenças monogênicas recessivas ${ }^{6}$. Com o avanço das pesquisas, muitos ensaios começaram a explorar o potencial da terapia gênica também em doenças adquiridas, como câncer, doenças cardiovasculares e infecciosas ${ }^{7}$.

Nas doenças monogênicas, a terapia gênica atuaria introduzindo a cópia de um gene funcional para substituir o gene defeituoso. Nas doenças poligênicas ou adquiridas, o tratamento seria utilizado para modificar informações celulares, estimular respostas terapêuticas, como produção de enzimas, proteínas e receptores, e inibir ou estimular respostas imunes ${ }^{4}$.

Um ponto importante era demonstrar, por meio de resultados de pesquisas, que os benefícios da terapia gênica para tratar doenças percebidas pela população como não fatais, mesmo que altamente limitantes, como artrite reumatoide e doenças cardiológicas, superariam os riscos e aumentariam a qualidade de vida desses pacientes ${ }^{8}$.

Para levar o material genético terapêutico às células-alvo, a terapia gênica utiliza veículos conhecidos como vetores, que são divididos em virais e não virais?. Esses vetores são moléculas de DNA com capacidade de carrear, transferir e expressar genes heterólogos para células-alvo do hospedeiro ${ }^{10}$.

Os vetores não virais utilizados na terapia gênica são os lipoplexos, poliplexos e lipopoliplexos, que são partículas químicas produzidas com o objetivo de transportar o DNA plasmidial até as células de interesse. Por muito tempo, esse tipo de vetor foi ignorado, devido a sua baixa eficiência na entrega dos genes de interesse; porém, atualmente, várias técnicas e novos compostos são investigados para melhorar a entrega do material terapêutico, como lipossoma catiônico, polímero catiônico, eletroporação e esonoporação 11,12 . Além desses vetores, existem também os virais, que estão sendo usados com maior frequência em ensaios clínicos de terapia gênica. Dentre eles, os mais comuns são os vetores retrovirais, adenovirais, vírus adenoassociados, herpesvirais e os poxvirais ${ }^{8,12}$

Neste trabalho de revisão, são explorados os aspectos mais relevantes no uso de vetores virais na terapia gênica, abordando, de forma breve, os vetores não virais para, então, de forma mais específica, discorrer sobre as características gerais e as aplicações dos principais vetores virais.

\section{VETORES NÃO VIRAIS}

Os vetores não virais são compostos de partículas biológicas sinteticamente produzidas, nas quais 0 plasmídeo de DNA, contendo o transgene terapêutico, é encapsulado ou ligado a um composto químico e, em seguida, liberado no alvo no momento da entrega. Além de DNA, os vetores não virais são capazes de transportar compostos sintéticos, como fragmentos de $\mathrm{RNA}^{13}$.

Os plasmídeos são fragmentos de DNA circular, os quais possuem uma existência independente nas células bacterianas, podendo ser transfectados de uma bactéria para outra. A incorporação de fragmentos de DNA heterólogo no plasmídeo vetorial permite a expressão e a tradução da proteína de interesse em células-alvo ${ }^{10}$.

Os vetores não virais são organizados em três tipos. O primeiro é o lipoplexo, à base de lipídios ou biodegradável, no qual o DNA plasmídeal é coberto por um lipídio, que pode ser catiônico, neutro ou aniônico, considerando que a carga superficial é uma propriedade físico-química importante. Até o momento, os vetores do tipo lipoplexos catiônicos são os mais utilizados, uma vez que as cargas opostas de plasmídeos, os quais são aniônicos e lipídios catiônicos, atraem-se eletrostaticamente, tornando - sistema mais estável. Uma carga final positiva aumenta a fixação do sistema aos proteoglicanos presentes na superfície de células-alvo e consequente condução para a endocitose. Vetores dos tipos neutros ou aniônicos tendem a ser menos estáveis que as partículas carregadas, devido à agregação entre eles e a fraca interação com as células, o que pode acarretar na liberação do sistema no espaço extracelular. Os vetores lipoplexos possuem vantagens de maior segurança e baixa citotoxicidade ${ }^{14,15}$.

Como desvantagem, os vetores lipoplexos tendem a se agregar sob condições fisiológicas, o que limita sua circulação e seu tempo de vida. Para contornar esse problema, uma das técnicas consiste em incorporar polietilenoglicol na superfície do lipoplexo, 
promovendo a redução da agregação e protegendo-o da opsonização por proteínas plasmáticas. A outra abordagem consiste em utilizar nanopartículas lipídicas sólidas para diminuir a agregação ${ }^{13}$.

○ segundo tipo de vetor não viral é o poliplexo ou vetor inorgânico. A maioria dos poliplexos consiste num complexo nanomérico formado entre um polímero catiônico e ácidos nucleicos. Esses complexos nanoméricos são estáveis, protegem o ácido nucleico da degradação e são competentes para entrar em células, geralmente por endocitose. A diferença entre poliplexo e lipoplexo é que o vetor poliplexo não é capaz de liberar a sua carga de DNA para o citoplasma, sendo necessária a cotransfecção com agentes endossoma-líticos ${ }^{12,14,15}$. Entre os poliplexos, a polietilenimina se destaca pela elevada eficiência de transfecção; contudo, o uso clínico desse poliplexo é limitado, devido aos seus efeitos citotóxicos. Com isso, buscam-se alternativas como o quitosano, um polímero biocompatível, porém com transfecção inferior à polietilenimina. Pesquisas utilizando quitosano com enxerto de nanopartículas de polietilenimina demonstraram o aumento da eficiência desse polímero sem diminuir seu perfil de segurança ${ }^{13}$.

Além dos vetores citados acima, existem também os vetores lipopoliplexos, que são produzidos unindo-se as propriedades vantajosas dos lipoplexos e dos poliplexos. Os lipopoliplexos são mais estáveis, apresentam maior reprodutibilidade e eficiência de transfecção ${ }^{16}$.

Para melhorar a transferência de genes por vetores não virais, como plasmídeos, são utilizadas técnicas de entrega do gene de interesse, como: os métodos químicos chamados de lipossoma catiônico, polímeros; e os métodos físicos, como as técnicas eletromecânicas de eletroporação e de biobalística ${ }^{8,12}$.

Os vetores não virais apresentam como vantagens: ausência de patogenicidade; baixo custo; facilidade de produção; e maior segurança em relação às abordagens virais ${ }^{14,17,18}$.

Como limitações, tais vetores apresentam: baixa eficiência de entrega do material genético; dificuldade em manter sua integridade no meio extracelular, por sofrerem degradação pelas nucleases; e dificuldade em manter a expressão do gene terapêutico ${ }^{13}$.

\section{VETORES VIRAIS}

Os vírus evoluem desenvolvendo estratégias aprimoradas para alcançar e penetrar em células-alvo específicas, onde eles sequestram a maquinaria celular para expressar seus genes e produzir sua progênie. Essa habilidade de entrar e expressar seus genes dentro das células é a base para o uso dos vírus como vetores $^{19}$.

Os vetores virais, como o próprio nome sugere, são vetores produzidos a partir de vírus com genomas de DNA ou RNA. Para construí-los, é preciso identificar as sequências virais necessárias para replicação e empacotamento do genoma viral, sendo também importante conhecer os mecanismos possíveis para entrega do gene de interesse (transgene) à célula-alvo 20 .

Nessa perspectiva, o genoma viral pode ser reorganizado visando a eliminar genes essenciais à replicação e à patogenicidade do vetor, para substituí-los por genes heterólogos e abrir espaço para a inserção do transgene ${ }^{21}$. Esse rearranjo torna o vírus parenteral apenas um transportador do material genético, ou seja, um vetor viral. Essa transferência genética tem como objetivos: estudar genes funcionais, corrigir defeitos genéticos, expressar proteínas terapêuticas e desenvolver vacinas para combater tumores e agentes infecciosos ${ }^{19}$.

Apesar de sua eficácia para transportar o material genético, alguns vírus apresentam um papel patogênico e, assim, os riscos de infecção e genotoxicidade devem ser levados em consideração, no que diz respeito à segurança do vetor de escolha ${ }^{13}$. Quando se projeta um vetor viral, é importante buscar características como: ausência de toxicidade para as células e de resposta imune contra o vetor e o transgene; capacidade de integração sítio-específico; estabilidade e expressão do gene em longo prazo ${ }^{20}$.

Cada vetor viral apresenta vantagens e limitações específicas, e a escolha do mesmo dependerá dos objetivos que se pretende alcançar ${ }^{10}$.

\section{VETORES BASEADOS EM RETROVÍRUS}

Os retrovírus são vírus envelopados, constituídos de um genoma de fita simples de RNA, de polaridade positiva, com cerca de 7 a $11 \mathrm{~kb}$ (kilobase) ${ }^{20}$. Após a entrada na célula-alvo, o genoma de RNA é transcrito em uma fita dupla de DNA, a qual é integrada no genoma celular ${ }^{22}$. Todos os genomas retrovirais possuem dois terminais longos de repetição (LTR) nas extremidades $5^{\prime}$ e $3^{\prime}$ que flanqueiam os genes gag, pol e env, os quais codificam as proteínas estruturais, as transcriptases, as integrases e as proteases ${ }^{19}$.

A localização da maioria das sequências atuantes em cis (do inglês cis-acting), na região terminal desses vírus (sítio de ligação do iniciador, região polipurínica e sinais de empacotamento), tem permitido a construção de retrovetores simples e eficientes, sendo amplamente utilizados para terapia gênica ${ }^{23}$. Nesse tipo de vetor, pode-se utilizar DNAs exógenos de até $8 \mathrm{~kb}$ para serem inseridos no lugar dos genes virais ${ }^{24}$.

Dentre os retrovírus, um deles tem sido amplamente estudado e utilizado para a construção de retrovetores: os lentivírus. Esses vírus possuem um genoma complexo e, além dos genes gag, pol e env, codificam dois genes regulatórios, tat e rev, essenciais para a expressão do genoma, além de um conjunto de genes acessórios ${ }^{22}$. Os lentivírus apresentam um melhor perfil de segurança referente à ativação de proto-oncogenes quando comparados a outros retrovírus ${ }^{13}$. Estudos mostraram que os vetores lentivirais têm uma menor tendência a se integrarem ao genoma do hospedeiro em locais que potencialmente podem causar câncer ${ }^{20}$. 
É importante ressaltar que os vetores lentivirais apresentam comportamentos diferentes com relação às células-alvo. Em células não divisíveis, como neurônios, hepatócitos e fibras musculares, os vetores mantêm-se estáveis em uma forma não integrada ao genoma do hospedeiro. Nas células com capacidade de divisão, os vetores se integram ao genoma da célula e são duplicados com o DNA do hospedeiro, representando então um risco de oncogênese, mesmo que menor em relação a outros retrovírus ${ }^{25}$.

Dentre os lentivírus, o vírus da imunodeficiência humana (HIV) é o que mais se destaca para construção de vetores. Os vetores baseados em HIV-1 foram desenvolvidos, sobretudo, com o objetivo de transduzir células não mitóticas. Outra vantagem desses vetores é a expressão prolongada nas células transduzidas ${ }^{26}$.

Os vetores de HIV estão entre os sistemas de transdução considerados mais eficientes in vivo e ex vivo; contudo, devido ao potencial de patogenicidade residual dos vetores de HIV, outros vetores estão sendo pesquisados, como o vírus da imunodeficiência felina, o vírus da anemia infecciosa equina e o vírus da imunodeficiência bovina ${ }^{19}$.

A glicoproteína do envelope viral dita o tropismo das partículas virais para células de um determinado hospedeiro, pela interação com os receptores nas células-alvo. $\bigcirc$ mecanismo de montagem (empacotamento) dos retrovírus permite a construção de vetores com substituição da proteína do envelope viral pela proteína de um vírus diferente, em um processo denominado de pseudotipagem, permitindo aumentar ou mudar o tropismo celular desses vetores ${ }^{27}$. Desse modo, a glicoproteína $G$ do vírus da estomatite vesicular tem sido utilizada, por exemplo, para aumentar o tropismo de retrovetores na transdução de neurônios e células da glia $^{28,29}$. Visando redirecionar o tropismo dos retrovetores para as células epiteliais do trato respiratório, a pseudotipagem foi utilizada com a glicoproteína M2 do influenza e a proteína $\mathrm{F}$ do vírus Sendai, observando-se uma melhora de $5 \%$ da eficiência na transdução de células ciliadas das vias respiratórias ${ }^{30}$.

Outra abordagem utilizando retrovírus tem sido a construção de vetores autoinativantes (self-inactivating - SIN). Os vetores do tipo SIN são construídos por meio da exclusão da sequência da região U3 do 3' LTR e, com isso, inativando o promotor endógeno do provírus ${ }^{26}$. $\bigcirc$ sistema de autoinativação visa diminuir os riscos de uma possível replicação viral desordenada e evita a codificação de sequências celulares adjacentes ao local de integração, reduzindo o risco de oncogênese de inserção ${ }^{31}$. Porém, mesmo com o uso de vetores SIN e promotores reguladores, ainda há o risco da ativação de genes próximos ao local de inserção, uma vez que a integração do DNA retroviral é um processo pseudoaleatório na célula hospedeira ${ }^{17}$.

Para diminuir esse efeito, alguns estudos têm abordado o uso do isolamento do genoma em torno do local de inserção (região flanqueada). Utilizam-se isoladores, pequenos elementos de DNA, que agem como barreira impedindo que elementos promotores e modificadores da cromatina influenciem na expressão de genes vizinhos. $\bigcirc$ isolador mais pesquisado é o cHS4, derivado do locus $\beta$-globina da galinha (Gallus gallus domesticus) ${ }^{3}$.

A deficiência da adenosina desaminase (ADA) resulta no acúmulo de substâncias tóxicas de metabólitos intra e extracelulares (trifosfatos de desoxiadenosina e de adenosina), comprometendo o desenvolvimento de linfócitos $T$, linfócitos $B$ e células natural killers ${ }^{32}$. Alguns estudos foram realizados utilizando vetores retrovirais para tratamento da ADA. $\mathrm{Na}$ década de 1980, a transferência dos genes foi realizada em células do cordão umbilical, ex vivo. A resposta foi insuficiente, devido ao reduzido número de células transduzidas ${ }^{33}$. Em 2000, 40 pacientes oriundos da Itália, do Reino Unido e dos Estados Unidos foram submetidos à terapia, utilizando vetores retrovirais para codificar o gene G-ADA ${ }^{34}$. Houve melhora do quadro de imunodeficiência e nenhum paciente desenvolveu leucemia, apenas uma pequena atividade de transcrição foi observada em clones de células $\mathrm{T}^{26}$. Em um ensaio clínico francês, células CD34+ foram infectadas com vetor retroviral para a entrega do transgene, com resultados não satisfatórios. Três pacientes evoluiram com leucemia após dois anos do procedimento, devido à ativação do proto-oncogene LMO2 $^{3}$. Entre 2003 e 2004, no Japão, duas crianças desenvolveram células gene-T corrigidas, porém em quantidade insuficiente para recuperação imune ${ }^{32}$.

Vetores baseados em retrovírus também foram utilizados para tratamento da imunodeficiência combinada grave ligada ao X1 (SCID-X1). A doença é causada por uma mutação no gene IL2RG, que conduz a uma expressão deficiente da cadeia gama comum, uma subunidade compartilhada por receptores de citoquinas, incluindo interleucinas 2, 4, 7, 9, 15 e 21, que desempenham importante papel no desenvolvimento e função dos linfócitos ${ }^{34}$. Os portadores da imunodeficiência apresentam desenvolvimento deficiente de células natural killers e células $T$, além de células $B$ não funcionais ${ }^{26}$. Em 2000, na França, 10 crianças portadoras de SCID-X1 foram submetidas à terapia gênica; no entanto, dois anos após o tratamento, duas crianças que haviam sido tratadas com altos níveis de material transgênico desenvolveram leucemia. Ficou comprovado que a inserção do vetor retroviral próximo ao promotor proto-oncogene LMO2 promoveu a expressão desordenada do referido promotor ${ }^{31,33}$.

A doença granulomatosa crônica, que é uma doença rara, hereditária, autossômica, recessiva e que provoca uma deficiência na função dos neutrófilos, devido à mutação no sistema NADPH oxidase, também foi alvo de terapia gênica ${ }^{26}$. Os dois primeiros testes realizados nos Estados Unidos, em 1995 e 1998, com um total de 10 pacientes, utilizaram vetores retrovirais. Em todos os pacientes, o número de neutrófilos corrigidos persistiu por alguns meses, todavia não resultou em benefício clínico em longo prazo ${ }^{34}$. Em 2006, em um ensaio 
clínico franco-suíço, foram inseridas células CD34 modificadas com vetor retroviral em três pacientes, com diminuição de recidivas de infecções por dois anos. Após esse período, um dos pacientes morreu por sepse, devido à reativação da doença, o que evidenciou a diminuição da expressão do transgene ${ }^{31}$.

Embora amplamente utilizados, os vetores baseados em retrovírus apresentam algumas desvantagens, como o alto risco de mutagênese de inserção, a baixa estabilidade e a transdução apenas em células em divisão. Por outro lado, é preciso considerar a possibilidade de integração do genoma do vetor dentro do genoma do hospedeiro, o que pode ser importante para algumas patologias, além do fato de que é pouco imunogênico e as partículas virais podem ser produzidas em altos títulos ${ }^{19}$.

\section{VETORES BASEADOS EM ADENOVÍRUS}

$\bigcirc$ uso de adenovírus humanos (HAdV) recombinante recebeu especial atenção, como veículo para transferência de genes, quando foi utilizado para infectar células do epitélio respiratório no tratamento de doenças como a fibrose cística. Desde então, foi rapidamente observado que tais vetores seriam os mais eficientes sistemas para a transferência de genes considerando uma ampla variedade de tecidos ${ }^{22}$.

Embora existam mais de 50 diferentes sorotipos de HAdV reportados, os vetores são primariamente derivados dos sorotipos 2 e 5 , os mais comuns, aos quais a maioria dos adultos tem sido exposta ${ }^{19}$.

Os adenovírus (AdV) são vírus não envelopados, com genoma de DNA de fita dupla ${ }^{35}$. Durante seu processo de replicação, os genes da região precoce 1 (El) são rapidamente transcritos e servem como reguladores transcricionais para $O$ processo de replicação do genoma. Os genes El (ElA e ElB), em combinação com os genes $E 2$ e $E 4$, são necessários para a replicação do genoma viral. O gene E3 é um gene sem função essencial para o vírus. Tardiamente na replicação, os genes que codificam as proteínas estruturais são transcritos, permitindo o empacotamento dos genomas recém-produzidos ${ }^{19,36}$.

$\mathrm{Na}$ primeira geração de vetores virais baseados em HAdV, o gene precoce ElA era deletado, inibindo a replicação viral e abrindo espaço para a inserção do transgene. No entanto, para reduzir o risco de reversão do mecanismo de replicação, o qual poderia ocorrer devido à recombinação com outros componentes do genoma viral ou celular, novos vetores passaram a ser produzidos, com deleção dos genes ElB e E3, os quais apresentam um importante papel na modulação da imunidade específica para $\mathrm{HAdV}^{37}$.

Assim como todos os vetores que são incompetentes na replicação por terem tido genes essenciais para a replicação deletados, as partículas de HAdV recombinantes só poderão ser produzidas a partir das chamadas linhagens celulares de empacotamento $35,36,38$. A nova geração de vetores baseados em HAdV é desprovida da maioria dos genes virais, contendo apenas os terminais de repetição e os sinais de empacotamento e sendo produzidos em células de empacotamento que expressam estavelmente a maioria dos genes virais necessários para a montagem do vírus ${ }^{39}$.

Estudos iniciais focavam no uso de vetores baseados em HAdV para o trato respiratório, alvo principal da infecção por HAdV. Atualmente, com o refinamento das técnicas de engenharia genética, esses vetores são capazes de infectar uma grande variedade de células pós-mitóticas, incluindo as células presentes em tecidos altamente diferenciados, como músculo esquelético, pulmão, cérebro e coração ${ }^{40}$.

Vetores baseados em HAdV foram utilizados na terapia gênica para a deficiência da ornitina transcarbamilase (OTC). Nessa doença ocorre um defeito no gene OTC que codifica a enzima OTC, responsável por converter a amônia, produto de excreção hepática, em ureia. $\bigcirc$ paciente evolui com hiperamonemia, provocando sintomas variados, como letargia, vômitos, convulsões, encefalopatia e cirrose. Em 1999, em um ensaio clínico utilizando vetor de HAdV, um paciente foi a óbito, devido à resposta inflamatória provocada pelo vetor. Além disso, as investigações revelaram que houve descumprimento do protocolo aprovado, sub-registro de eventos adversos e divulgação insuficiente de conflitos de interesse ${ }^{41}$.

Os vetores baseados em HAdV também têm sido desenvolvidos e estudados para o tratamento de doenças não monogênicas, como câncer ${ }^{42,43,44,45}$, artrite reumatoide ${ }^{8}$ aids $^{26}$.

Uma das principais desvantagens no uso desses vetores está na alta imunidade estimulada por eles, com casos já relatados de morte devido à severa resposta antivetor gerada pela excessiva inoculação do vetor. Diante disso, novos vetores, baseados em AdV derivados de vírus parentais que raramente circulam em humanos, estão sendo desenvolvidos ${ }^{19}$.

\section{VETORES BASEADOS EM VÍRUS ADENOASSOCIADOS}

$\mathrm{O}$ vírus adenoassociado (AAV) possui um genoma constituído por DNA linear de fita simples, com cerca de 4,7 kbp, protegido por um capsídeo icosaédrico. genoma desse vírus é composto de dois genes: rep, replicase requerida para a replicação do genoma viral; e cap, o qual codifica proteínas estruturais. Os genes são flanqueados por duas sequências palindrômicas denominadas ITRs (repetições terminais invertidas) ${ }^{13}$.

Para a sua replicação, o AAV precisa da coinfecção com vírus auxiliares, como os vírus herpes simples, AdV e vírus do papiloma humano (HPV). Na falta de um vírus auxiliar, o genoma do AAV pode persistir no hospedeiro como um epissoma (unidade replicadora que atua de forma independente) e pode se integrar em local específico no genoma do hospedeiro, no cromossomo 19, sendo esse processo mediado pela proteína rep ${ }^{46}$.

Após a reativação por infecção com um vírus auxiliar, ocorre um conjunto de eventos que conduz à produção de partículas infecciosas. Esses eventos incluem a ativação precoce do gene rep, o resgate 
do genoma do AAV e, finalmente, a geração de formas replicativas de DNA que também servem como modelos para a síntese de proteínas rep e cap ${ }^{47}$.

Para desenvolver vetores baseados em AAV, os genes rep e cap são deletados e fornecidos in trans. Em vetores de AAV recombinante (rAAV), os genes virais são substituídos por um transgene que carrega o promotor, $\circ$ gene de interesse e o local $\mathrm{pA}^{18}$. Inicialmente, essa função era realizada pelos adenovírus auxiliares, que possuíam os genes importantes para o empacotamento e para a replicação do AAV recombinante. No entanto, devido aos problemas de produção, no qual se tornava difícil separar o vírus auxiliar do vetor recombinante no produto final, os adenovírus foram substituídos por plasmídeos que expressam os genes ausentes ${ }^{19,20,48}$.

Em 2004, Nathwani et al. ${ }^{49}$ reportaram o uso de vetores de AAV para tratamento da hemofilia B ou doença de Christmas, que é hereditária, recessiva e ligada ao $X$, na qual ocorre deficiência do fator IX ou fator Christmas, uma das principais proteínas da cascata da coagulação ${ }^{49}$. Apesar da existência da hemofilia $A$, que é decorrente da deficiência do fator VIII, as pesquisas se concentram no tipo B, pois as regiões e sequências reguladoras do fator IX podem ser facilmente codificadas no vetor viral adenoassociado ${ }^{50}$. A hemofilia B caracteriza-se por episódios recorrentes de sangramentos. No referido estudo $^{49}$, foi realizado um ensaio clínico com 10 pacientes portadores de hemofilia $B$, utilizando vetores de $\mathrm{AAV}$, sorotipo self-complementary 8 (AAV8), para aumentar os níveis do fator IX por um período de até 16 meses. Os resultados foram promissores, pois observou-se redução dos episódios hemorrágicos e do uso profilático de concentrados de fator IX.

Esse tipo de vetor também tem sido estudado para o tratamento da deficiência familiar da lipoproteína lipase, uma doença hereditária autossômica, recessiva, causada por mutação no gene da lipoproteína lipase (LPL), o qual codifica uma enzima produzida no tecido adiposo, no músculo esquelético e no músculo cardíaco e é responsável pelo metabolismo de lipoproteínas ricas em triglicerídeos ${ }^{51}$. Após várias pesquisas, três ensaios clínicos, com um total de 27 pacientes, utilizaram vetor AAV1 para expressar uma variante do LPL transgene, denominado alipogene tiparvovec, com excelentes resultados ${ }^{52}$.

Dentre as doenças não monogênicas, nas quais vetores adenoassociados têm sido reportados, estão a artrite reumatoide ${ }^{53}$ e a doença de Parkinson ${ }^{25,31,54}$.

No entanto, os vetores possuem algumas desvantagens, como a capacidade de clonagem limitada e imprópria para a maioria dos genes terapêuticos. Como o AAV requer a conversão da fita simples de DNA em fita dupla de DNA antes que a expressão do gene comece, isso o torna um vetor de expressão muito lenta para algumas aplicações in vivo ${ }^{48}$. Dentre as vantagens para o uso dos vetores de $\mathrm{AAV}$, pode-se citar a baixa imunogenicidade, o amplo tropismo celular, o uso de vírus parental não patogênico para o hospedeiro e a capacidade de transdução em células que estejam ou não em divisão. Os vetores AAV podem ser utilizados em uma ampla variedade de células, incluindo células musculares, células do sistema nervoso central e hepatócitos, sendo o vetor de escolha em cerca de 100 ensaios clínicos com terapia gênica para doenças monogênicas ${ }^{55}$.

\section{VETORES BASEADOS EM HERPESVÍRUS}

Os herpesvírus humanos (HHV) fazem parte da família Herpesviridae, são vírus de DNA envelopados e causam infecções líticas, latentes e/ou persistentes ou recorrentes ${ }^{35}$. $\bigcirc \mathrm{HHV}$ é de particular interesse para investigadores da terapia gênica, em especial - herpesvírus do tipo 1 (HHV-1), um vírus de DNA neurotrópico que abriga mais de 80 genes categorizados entre essenciais e não essenciais, de acordo com sua necessidade de replicação ${ }^{7}$.

A presença dos muitos genes não essenciais permite ao vírus um espaço de cerca de 30 a $50 \mathrm{kbp}$ para a inserção de genes heterólogos, o que os torna excelentes vetores para a terapia gênica ${ }^{56}$.

Durante o processo de replicação, os HHV codificam três grandes grupos de proteínas ${ }^{35}$ :

a) Proteínas iniciais imediatas $(\alpha)$, que consistem em proteínas importantes na regulação da transcrição gênica e controle da célula;

b) Proteínas iniciais ( $\beta$ ), que consistem em mais fatores de transcrição e enzimas, incluindo a DNA polimerase;

c) Proteínas tardias $(\gamma)$, que consistem principalmente em proteínas estruturais geradas após o início da replicação do genoma viral.

Atualmente, três diferentes classes de vetores são derivadas de HHV-1: vetores atenuados competentes em replicação; vetores recombinantes incompetentes em replicação; e amplicons (vetores dependentes de vírus defectivo-auxiliares). Para desenvolver os vetores atenuados competentes em replicação, são deletados os genes não essenciais para a replicação. Os vetores incompetentes em replicação são desenvolvidos pela deleção de um ou mais genes iniciais imediatos, os quais são fornecidos in trans por uma cepa de HHV competente em replicação, por um plasmídeo ou por células que expressam constitutivamente o gene deletado. A terceira classe de vetores, os amplicons, são os mais seguros por carregarem o mínimo de sequências virais e apresentarem baixa toxicidade e imunogenicidade ${ }^{57}$.

A geração de HHV geneticamente construídos tem sido utilizada principalmente para o tratamento de doenças neuronais. Além das células não proliferativas, como as células neuronais, os vetores baseados em HHV também são desenvolvidos para transduzir células em divisão, como as células da glia do sistema nervoso central ${ }^{13}$.

principal obstáculo no uso dos vetores baseados em HHV é a imunidade pré-existente, que eficientemente inativa as partículas vetoriais e elimina células transduzidas que expõem, em sua superfície, proteínas do HHV codificadas pelo vetor ou empacotadas na partícula. Outro fator preocupante seria a recombinação 
entre o vetor de HHV e o genoma selvagem do vírus presente na forma latente em células do hospedeiro ${ }^{19}$.

Como vantagens no uso desse tipo de vetor, reporta-se o amplo tropismo celular, a possibilidade de inserção de DNA heterólogo grande (até 50 kbp), o tropismo natural por células neuronais (vetores de $\mathrm{HHV}$ ) e células B (vetores de vírus Epstein Barr), a boa adequação como vetores oncolíticos (altamente tóxicos para alguns tumores proliferativos) e a produção de partículas em altos títulos ${ }^{35,56}$.

Muitos estudos demonstraram uma expressão transgênica estável em longo prazo no sistema nervoso quando utilizados vetores baseados em HHV-1. Os estudos pré-clínicos, utilizando modelos de doença neurológica, como glioma, neuropatia periférica, dor crônica e neurodegeneração, reportaram resultados promissores ${ }^{58,59,60}$.

\section{VETORES BASEADOS EM POXVÍRUS}

Os poxvírus, incluindo o vírus da varíola (VARV), são partículas envelopadas complexas, com um genoma grande de DNA de fita dupla, de aproximadamente $190 \mathrm{kbp}$ de comprimento ${ }^{61}$. Outro importante fator a ser considerado, é que esses vírus apresentam um alto número de genes (cerca de 250) e muitos deles podem ser deletados por serem dispensáveis para a replicação ${ }^{62}$.

O vírus Vaccinia (VACV) é o membro protótipo da família Poxviridae e, por isso, a maioria das pesquisas, utilizando vetores de poxvírus, tem sido focada em sua utilização. Assim como para todos os poxvírus, o VACV tem um ciclo completo de replicação dentro do citoplasma da célula hospedeira, apesar de ser um vírus de $\mathrm{DNA}^{63}$

O VACV pode abrigar genes heterólogos de até $25 \mathrm{kbp}$, tornando-os muito úteis para a expressão de genes maiores. Devido a sua capacidade de alta expressão do transgene e suas propriedades citolíticas, os vetores de poxvírus são mais utilizados para a produção de proteínas recombinantes, terapia contra o câncer e vacinação ${ }^{64}$.

Para a construção de vetores baseados em poxvírus recombinantes, é necessário considerar dois pontos: os locais de inserção no genoma do VACV e os genes repórteres introduzidos. $O$ genoma do VACV tem cerca de sete locais de inserção conhecidos, onde genes heterólogos podem ser inseridos. $O$ local de inserção escolhido depende principalmente da aplicação futura dos vírus recombinantes ${ }^{46,63,65}$.

Os vetores baseados em VACV desenvolvidos atualmente são altamente atenuados, restritos ao hospedeiro e utilizam cepas com quase nenhuma capacidade de replicação. As cepas mais utilizadas incluem o vírus Vaccinia Ankara modificado (MVA), a cepa NYVAC derivada da cepa Copenhagen, Avipoxvirus ALVAC e TROVAC (infectam aves) ${ }^{66}$. O perfil de eficácia, quanto à capacidade de ativação da resposta imune, parece ser variado entre as diferentes cepas, sendo MVA a cepa que parece eliciar uma menor resposta imune ${ }^{67}$.
Os vetores baseados em VACV são capazes de eliciar um efeito antitumoral em tumores hipóxicos. Esses tumores sólidos são caracterizados por regiões de baixo aporte de oxigênio, com consequente surgimento de áreas intratumorais mal vascularizadas, sendo resistentes à radioterapia ou à quimioterapia. Os vetores baseados em VACV são atrativos para tumores hipóxicos de difícil tratamento, como os tumores pancreáticos ${ }^{68}$. Uma das abordagens utilizadas para a construção de mutantes de poxvírus oncolíticos consiste na deleção do gene de timidina quinase do genoma viral. Um estudo demonstrou o uso, em ensaios clínicos de fase II, do vetor oncolítico denominado JX-594 para tratamento de pacientes com câncer de fígado. Para tal propósito, o gene heterólogo GM-CSF (fator estimulador de colônias de granulócitos e macrófagos) foi inserido no lócus de timidina quinase, gerando um vetor seletivo para o tumor ${ }^{69}$.

Os vetores poxvírus apresentam, como principal vantagem, os múltiplos locais para a inserção do transgene. No entanto, como desvantagens, esses vetores são potencialmente citotóxicos, apresentam uma expressão transiente do transgene e são altamente imunogênicos ${ }^{19}$.

\section{CONCLUSÃO}

O elemento essencial para a terapia gênica são os vetores, veículos de entrega do material gênico, que são divididos, quanto à forma de construção, em virais e não virais. Até o presente momento, os vetores virais são considerados mais eficientes e frequentemente utilizados nas pesquisas e ensaios clínicos, por isso foram o objeto de estudo deste trabalho.

O tratamento de muitas doenças, por meio da terapia gênica com vetores virais, vem sendo pesquisado, alcançando-se bons resultados; porém, houve casos em que ocorreram toxicidade, mutações oncogênicase até mesmo óbito do paciente, gerando preocupaçãoperante as pesquisas.

Os vetores virais são eficazes para entregar o agente terapêutico, todavia apresentam risco de infecção e de estimular respostas imunes e oncogênicas. É importante aumentar os esforços nas pesquisas que visem 0 desenvolvimento de novas metodologias, assim como aprimorar o padrão de eficiência e segurança dos vetores virais já existentes.

\section{CONFLITOS DE INTERESSE}

Os autores declaram não haver conflitos de interesse em relação à pesquisa.

\section{CONTRIBUIÇÃO DOS AUTORES}

Todos os autores contribuíram com a idealização do estudo, a análise e a interpretação dos dados e com a redação do manuscrito, aprovando a versão final publicada. Declaram-se responsáveis pelo conteúdo integral do artigo, garantindo sua precisão e integridade. 


\section{REFERÊNCIAS}

1 Duncan E, Brown M, Shore EM. The revolution in human monogenic disease mapping. Genes (Basel). 2014;5(3):792-803.

2 Flotte TR. Gene therapy: the first two decades and the current state-of-the-art. J Cell Physiol. 2007 Nov;213(2):301-5.

3 Porteus MH, Connelly JP, Pruett SM. A look to future directions in gene therapy research for monogenic diseases. PLoS Genet. 2006 Sep;2(9):1285-92.

4 Gardlík R, Pálffy R, Hodosy J, Lukács J, Turňa J, Celec P. Vectors and delivery systems in gene therapy. Med Sci Monit. 2005 Apr; 11 (4):RA1 10-21.

5 Guan X, Goddard MA, Mack DL, Childers MK. Gene therapy in monogenic congenital myopathies. Methods. 2016 Apr;99:91-8.

6 Miniet RSG, Fraguela MEG. Terapia genica. Perspectivas y consideraciones eticas en relacion con su aplicacion. Rev Haban Cienc Med. 2008 ene-mar; $7(1): 1-15$.

7 Tani J, Faustine, Sufian JT. Updates on current advances in gene therapy. West Indian Med J. 2011 Mar;60(2): 188-94.

8 Woods JM, Sitabkhan Y, Koch AE. Gene therapy for rheumatoid arthritis: recent advances. Curr Gene Ther. 2008 Feb;8(1):24-41.

9 Dimitriou R, Jones E, McGonagle D, Giannoudis PV. Bone regeneration: current concepts and future directions. BMC Medicine. 2011;9:66.

10 Khan $\mathrm{KH}$. Vectors used in gene manipulation - a retrospective. Adv Biotech J. 2009 Aug; $1-8$.

11 Al-Dosari MS, Gao X. Nonviral gene delivery: principle, limitations, and recent progress. AAPS J. 2009 Dec; 11 (4):671-81.

12 Nayerossadat N, Maedeh T, Ali PA. Viral and nonviral delivery systems for gene delivery. Adv Biomed Res. 2012 Apr-Jun; 1 (2):27.

13 Chira S, Jackson CS, Oprea I, Ozturk F, Pepper MS, Diaconu I, et al. Progresses towards safe and efficient gene therapy vectors. Oncotarget. 2015 Oct;6(31):30675-703.

14 Ramamoorth M, Narvekar A. Non viral vectors in gene therapy - an overview. J Clin Diagn Res. 2015 Jan;9(1):GE01-6.

15 Burlamaque Neto AC. Terapia gênica: contribuição para uma abordagem farmacológica [dissertação]. Porto Alegre (RS): Universidade Federal do Rio Grande do Sul, Instituto de Ciências Básicas da Saúde; 2005. 58 p.
16 Germershaus O, Nultsch K. Localized, non-viral delivery of nucleic acids: opportunities, challenges and current strategies. Asian J Pharm Sci. 2015 Jun;10(3): 159-75.

17 Naim C, Yerevanian A, Haijar RJ. Gene therapy for heart failure: where do we stand? Curr Cardiol Rep. 2013 Feb; 15:333.

18 Wang H, Wei F, Li H, Ji X, Li S, Chen X. Combination of oncolytic adenovirus and endostatin inhibits human retinoblastoma in an in vivo mouse model. Int J Mol Med. 2013 Feb;31 (2):377-85.

19 Vannucci L, Lai M, Chiuppesi F, Ceccherini-Nelli L, Pistello M. Viral vectors: a look back and ahead on gene transfer technology. New Microbiol. 2013 Jan;36(1): $1-22$.

20 Coura R. Viral vectors in neurobiology: therapeutic and research applications. In: Adoga MP, editor. Molecular virology. Shanghai: InTech; 2012. Capítulo 5; p. 75-93.

21 Coune PG, Schneider BL, Aebischer P. Parkinson's disease: gene therapies. Cold Spring Harb Perspect Med. 2012 Apr;2(4):a009431.

22 Kay MA, Glorioso JC, Naldini L. Viral vectors for gene therapy: the art of turning infectious agents into vehicles of therapeutics. Nat Med. 2001 Jan;7(1):33-40.

23 Rosenberg SA, Blaese RM, Brenner MK, Deisseroth $A B$, Ledley FD, Lotze MT, et al. Human gene marker/ therapy clinical protocols. Hum Gene Ther. 2000 Apr; 11 (6):919-79.

24 Miller AD. Development and applications of retroviral vectors. In: Coffin JM, Hughes SH, Varmus HE, editors. Retroviruses. Cold Spring Harbor (NY): Cold Spring Harbor Laboratory Press; 1997.

25 Kotterman MA, Chalberg TW, Schaffer DV. Viral vectors for gene therapy: translational and clinical outlook. Annu Rev Biomed Eng. 2015 Dec; 17:63-89.

26 Nienhuis AW. Development of gene therapy for blood disorders: an update. Blood. 2013 Aug;122(9):1556-64.

27 Dalba C, Bellier B, Kasahara N, Klatzmann D. Replication-competent vectors and empty virus-like particles: new retroviral vector designs for cancer gene therapy or vaccines. Mol Ther. 2007 Mar; 15(3):457-66.

28 Naldini L, Blömer U, Gallay P, Ory D, Mulligan R, Gage $\mathrm{FH}$, et al. In vivo gene delivery and stable transduction of nondividing cells by a lentiviral vector. Science. 1996 Apr;272(5259):263-7.

29 Kordower JH, Bloch J, Ma SY, Chu Y, Palfi S, Roitberg $B Z$, et al. Lentiviral gene transfer to the nonhuman primate brain. Exp Neurol. 1999 Nov;160(1):1-16. 
30 Griesenbach U, Alton EWFW. Progress in gene and cell therapy for cystic fibrosis lung disease. Curr Pharm Des. 2012;18(5):642-62.

31 Edelstein ML, Abedi MR, Wixon J. Gene therapy clinical trials worldwide to 2007 - an update. J Gene Med. 2007 Oct;9(10):833-42.

32 Ghosh S, Thrasher AJ, Gaspar HB. Gene therapy for monogenic disorders of the bone marrow. $\mathrm{Br}$ J Haematol. 2015 Oct;171(2):155-70.

33 Boudes PF. Gene therapy as a new treatment option for inherited monogenic diseases. Eur J Intern Med. 2014 Jan;25(1):31-6.

34 Mukherjee S, Thrasher AJ. Gene therapy for PIDs: progress, pitfalls and prospects. Gene. 2013 Aug;525(2):174-81.

35 Murray PR, Rosenthal KS, Pfaller MA. Microbiologia médica. 6. ed. São Paulo: Elsevier; 2009.

36 Verma IM, Weitzman MD. Gene therapy: twenty-first century medicine. Annu Rev Biochem. 2005 Jul;74:711-38.

37 Campos SK, Barry MA. Current advances and future challenges in adenoviral vector biology and targeting. Curr Gene Ther. 2007 Jun;7(3):189-204.

38 Walther W, Stein U. Viral vectors for gene transfer: a review of their use in the treatment of human diseases. Drugs. 2000 Aug;60(2):249-71.

39 Wang L, QI X, Shen R, Sun Y, Tuveson DA. A shRNA silencing a non-toxic transgene reduces nutrient consumption and increases production of adenoviral vectors in a novel packaging cell. J Cell Physiol. 2009 May;219(2)365-71.

40 Howarth JL, Lee YB, Uney JB. Using viral vectors as gene transfer tools (Cell Biology and Toxicology Special Issue: ETCS-UK 1 day meeting on genetic manipulation of cells). Cell Biol Toxicol. 2010 Feb;26(1): $1-20$.

41 Choi DE, Lee KW, Shin YT, Na KR. Hyperammonemia in a patient with late-onset ornithine carbamoyltransferase deficiency. J Korean Med Sci. 2012 May;27(5):556-9.

42 Xu HN, Huang WD, Cai Y, Ding M, Gu JF, Wei N, et al. HCCS1-armed, quadruple-regulated oncolytic adenovirus specific for liver cancer as a cancer targeting gene-viro-therapy strategy. Mol Cancer. $2011 ; 10: 133$.

43 He B, Huang X, Liu X, Xu B. Cancer targeting geneviro-therapy for pancreatic cancer using oncolytic adenovirus ZD55-IL-24 in immune-competent mice. Mol Bio Rep. 2013 Sep;40(9):5397-405.

44 Roizman B, Knipe D, Whitley R. Herpes simplex viruses. In: Fields BN, Knipe DM, Howley PM, editors. Fields virology. 5th ed. Philadelphia: Lippincott Williams \& Wilkins; 2007. p. 2501-602.
45 Wu CL, Shieh GS, Chang CC, Yo YT, Su CH, Chang $M Y$, et al. Tumor-selective replication of an oncolytic adenovirus carrying Oct-3/4 response elements in murine metastatic bladder cancer models. Clin Cancer Res. 2008 Fev; 14(4):1228-38.

46 Moore AR, Dong B, Chen L, Xiao W. Vaccinia virus as a subhelper for AAV replication and packaging. Mol Ther Methods Clin Dev. 2015 Nov;2:15044.

47 Alazard-Dany N, Nicolas A, Ploquin A, Strasser R, Greco A, Epstein AL, et al. Definition of herpes simplex virus type 1 helper activities for adenoassociated virus early replication events. PLoS Pathog. 2009 Mar;5(3):e1000340.

48 Coura RS, Nardi NB. The state of the art of adenoassociated virus-based vectors in gene therapy. Virol J. 2007 Oct;4:99.

49. Nathwani AC, Reiss UM, Tuddenham EGD, Rosales C, Chowdary P, Mclntosh J, et al. Long-term safety and efficacy of factor IX gene therapy in hemophilia B. N Engl J Med. 2014 Nov;371(21):1994-2004.

50 Daya S, Berns Kl. Gene therapy using adeno-associated virus vectors. Clin Microbiol Rev. 2008 Oct;21 (4):583-93.

51 Nierman MC, Rip J, Twisk J, Meulenberg JJM, Kastelein JJP, Stroes ESG, et al. Gene therapy for genetic lipoprotein lipase deficiency: from promise to practice. Neth J Med. 2005 Jan;63(1):14-9.

52 Ferreira $V$, Petry $H$, Salmon F. Immune responses to AAV-vectors, the Glybera example from bench to bedside. Front Immunol. 2014 Mar;5: 82.

53 Wehling P, Reinecke J, Baltzer AWA, Granrath $M$, Schulitz KP, Schultz C, et al. Clinical responses to gene therapy in joints of two subjects with rheumatoid arthritis. Hum Gene Ther. 2009 Feb;20(2): 97-101.

54 Mueller C, Flotte TR. Clinical gene therapy using recombinant adeno-associated virus vectors. Gene Ther. 2008 Jun; 15:858-63.

55 Grieger JC, Samulski RJ. Chapter twelve - adenoassociated virus vectorology, manufacturing, and clinical applications. In: Friedmann T, editor. Methods in enzymology. San Diego (CA): Elsevier; 2012. Chapter 507, Gene transfer vectors for clinical application; p. 229-54.

56 Kukhanova MK, Korovina AN, Kochetkov SN. Human herpes simplex virus: life cycle and development of inhibitors. Biochemistry (Mosc). 2014 Dec;79(13):1635-52.

57 Marconi P, Manservigi R, Epstein AL. HSV-1-derived helper-independent defective vectors, replicating vectors and amplicon vectors, for the treatment of brain diseases. Curr Opin Drug Discov Devel. 2010 Mar;13(2):169-83. 
58 Manservigi R, Argnani R, Marconi P. HSV recombinant vectors for gene therapy. Open Virol J. 2010;4:123-56.

59 Fraefel C, Marconi P, Epstein AL. Herpes simplex virus type 1-derived recombinant and amplicon vectors. In: Merten OW, Al-Rubeai M, editors. Viral vectors for gene therapy: methods and protocols. New York (NY): Humana Press. 2011 . p. 303-43. (Methods in molecular biology; 737).

60 Goins WF, Krisky DM, Wechuck JB, Wolfe D, Huang S, Glorioso JC. Generation of replication-competent and -defective HSV vectors. Cold Spring Harb Protoc. 2011 May;2011 (5):pdb.prot5615.

61 Babkin IV, Babkina IN. Molecular dating in the evolution of vertebrate poxviruses. Intervirology. $2011 ; 54(5): 253-60$.

62 Schramm B, Locker JK. Cytoplasmic organization of poxvirus DNA replication. Traffic. 2005 Oct;6(10):839-46.

63 Ali SA, Baldanta S, Fernández-Escobar M, Guerra S. Use of reporter genes in the generation of vaccinia virus-derived vectors. Viruses. 2016 May;8(5):134.
64 Kim JW, Gulley JL. Poxviral vectors for cancer immunotherapy. Expert Opin Biol Ther. 2012 Apr; 12(4):463-78.

65 Nascimento IP, Leite LCC. Recombinant vaccines and the development of new vaccine strategies. Braz J Med Biol Res. 2012 Dec;45(12):1102-11.

66 Gómez CE, Nájera JL, Krupa M, Perdiguero B, Esteban M. MVA and NYVAC as vaccines against emergent infectious diseases and cancer. Curr Gene Ther. 2011 Jun;11(3):189-217.

67 Ramírez JC, Gherardi MM, Esteban M. Biology of attenuated modified vaccinia virus Ankara recombinant vector in mice: virus fate and activation of $\mathrm{B}$ - and $\mathrm{T}$-cell immune responses in comparison with the Western Reserve strain and advantages as a vaccine. J Virol. 2000 Jan;74(2):923-33.

68 Hiley CT, Yuan M, Lemoine NR, Wang Y. Lister strain vaccinia virus, a potential therapeutic vector targeting hypoxic tumours. Gene Ther. 2010 Feb; 17(2):281-7.

69 Heo J, Reid T, Ruo L, Breitbach CJ, Rose S, Bloomston $M$, et al. Randomized dose-finding clinical trial of oncolytic immunotherapeutic vaccinia JX-594 in liver cancer. Nat Med. 2013 Mar;19(3):329-36. 